\title{
Network Interaction of Science, Education and Production
}

\author{
Baurzhan Tolysbayev ${ }^{1, *}$, Talgat Uteubayev², Gulnur Amirova ${ }^{1}$ \\ ${ }^{1}$ L.N. Gumilyov Eurasian national university, Satpayev Str. 2, Nur-Sultan, Republic of Kazakhstan, \\ 010008 \\ ${ }^{2}$ Eurasian Industrial Chemical Group LLP, Karaganda, Republic of Kazakhstan
}

\begin{abstract}
The study examines the scientific, educational and production network, which is a systematic activity for the development of innovative educational programs as a kind of joint capital of industrial enterprises, scientific organizations and educational institutions, which is the basis for the development of all own capital of participants of such network interaction. Mechanism of network interaction within the framework of scientific, educational and production network on the basis of the paradigm of "open" innovations is associated with the creation of conditions for the development of innovative capital of the network entities, training of highly qualified personnel of meneral and vocational education with the necessary competencies in the field of generation and dissemination of new knowledge, as well as improving the effectiveness and efficiency of the entities in the course of the scientific, educational and production network. Research was composed to measure variation in the economic development and innovation in Kazakhstan required in times of increasing global competition.
\end{abstract}

\section{Introduction}

In modern conditions, the integration of education, science and production should be considered as a top priority aimed at training highly qualified specialists who meet the needs of the labor market in the development of an innovative economy.

Effective interaction of universities with the labor market and individual employers as a whole requires the development of a comprehensive strategic partnership of all stakeholders, the purpose of which is to combine human, financial, material, technical and other resources for mutually beneficial cooperation.

In recent years, there has been a tendency on the part of the state to seek to establish interaction between enterprises and educational institutions. This interaction, as a rule, should include:

- involvement of enterprises in the formation of educational programs of universities, participation in training and organization of professional practices, development of professional competencies of students in demand in the modern labor market;

- implementation of joint research activities in various innovative areas;

*Corresponding author: tolysbaev_b@enu.kz 
- employment of University graduates;

- additional grants and scholarships for students and teachers;

- financing of targeted training of students;

- creation of material and social conditions for the adaptation and consolidation of young professionals in enterprises.

Partnership of companies with universities - is, on the one hand, staffing of the real sector of the economy, taking into account the selected promising areas of its development, and on the other - it is expressed in a special form of business, when there is a pool of resources of several subjects, in the framework of research projects.

Thus, the creation of a system of training for enterprises can be considered in two directions.

The first direction - universities carry out educational activities in cooperation with enterprises. The employer takes an active part in the formation of professional standards and professional competences of future specialists, innovative educational programs, systems of mentoring of graduates and professional adaptation are developed together with enterprises.

It should also be noted that the specifics of this trajectory is the practical content of the educational process, its organization on the basis of "centers for collective use", the introduction of the project method of training in the educational process, the organization of students ' practices, internships at enterprises, the implementation of project, diploma works on the order of enterprises, corporate competitions, etc.

The second direction is the training of specialists not only for specific enterprises, but also capable of independently organizing their own enterprise. This is the creation of "new employers". In the implementation of this direction it is necessary to note the significant role of business incubators, allowing students to form a special entrepreneurial competence.

As follows from the above, the main result of the activities of the University of a new research type in the field of training is a creative person who is capable of self-development during life, to research, creative approach to all phenomena and processes of our time.

\section{Literature review}

The rapid development of high-tech industries, the acceleration of the introduction of innovative scientific developments in mass production, the reduction of cycles of renewal of industrial equipment, the processes of Informatization of the economy, changing the requirements of employers to the system of training and retraining of specialists in content and structure, impose new requirements for education, science and business. Under these conditions, the triad "education-science-production" is no longer able to effectively adapt and develop to changes in isolation, independently of each other. Domestic and foreign researchers [1-5] noted that in the innovation economy, the efficiency and effectiveness of the interaction of economic activities is significantly increased by the organization of integration processes in a network structure as a more perfect modification of the adaptive structures of the management system of complex social and economic systems.

The advantages of using network structures in different economic systems are:

- concentration of network members' activities on their key unique processes and competencies;

- high adaptability to changing external conditions, quick response to changes in market conditions;

- elimination of duplication of a number of functions performed by network members;

- significant reduction of costs, their rational structure;

- replication of best practices, effective mechanism of information exchange between network participants; 
- in the implementation of projects in the network to engage in joint activities of competent partners who have the necessary resource potential [6-7].

It should also be noted that the use of the network approach in the integration processes allows for the effective functioning of both the entire socio-economic system and each of its individual elements.

At the end of the XX century, abroad started to pay great attention to the study of the role of network structures in the economy. In this regard, the emphasis of economists has shifted from integration to the creation of economic innovation structures and institutions of the network type. Network forms of organization are widespread in various fields of activity.

Thus, at the beginning of the XXI century the use of network approach in the activities of leading Western universities became the dominant direction [8-10]. This was due to the following reasons:

- the growth of environmental variability, the need for rapid adaptation of universities to these changes;

- increased international competition;

- expansion of the international space of universities;

- low efficiency of common forms of cooperation of international scientific and educational cooperation in solving complex problems;

- striving for a more efficient and deeper division of labour;

- development of world communication networks and network computer technologies [11-13].

The transformations taking place in the system of higher education, associated with the transition of Kazakhstan to a new stage of socio-economic development of society, also identified the need for the organization and development of network formations in the economy.

\section{Results and discussion}

The study examines the scientific, educational and production network, which is a systematic activity for the development of innovative educational programs as a kind of joint capital of industrial enterprises, scientific organizations and educational institutions, which is the basis for the development of all own capital of participants of such network interaction.

In the process of formation of this joint capital there is a transfer of accumulated individual knowledge in the on-net knowledge, fixing them in the corporate database for wide use by all participants of the scientific, educational and production network. A key feature of corporate knowledge is the possibility of its further development in the "open source" mode, that is, knowledge from the network can always be taken, improved and returned back to the network. Therefore, knowledge is not just stored in the network, but also developed, leading to the emergence of completely new opportunities for the development of network interaction participants.

In General, the development of scientific, educational and production network (SEPN) is designed to solve the following main tasks:

- for subjects of educational activity: generation of new knowledge, intellectual property in the process of training, the implementation of advanced training of specialists focused on the latest products and technologies, the introduction of the results of intellectual activity in the research and educational process;

- for the subjects of scientific activity: implementation of the results of intellectual activity in production, generation of intellectual property, new knowledge in the process of joint $\mathrm{R} \& \mathrm{D}$, training of creative individuals with research and professional competencies 
necessary for the creation and development of innovative entrepreneurship;

- for subjects of industrial activity: development of existing industries susceptible to innovation, and / or implementation of complex projects to create high-tech production, the implementation of training and retraining of specialists with the necessary professional competencies for the organization and development of production; according to the paradigm of "open innovation" the use of R \& D results and external knowledge to create, organize and develop additional value [14-16].

The study of foreign and domestic experience in the development of integration processes of subjects of educational, scientific, production and research activities allowed us to offer a scheme of network interaction of education, science, production. This scheme will help to increase their dynamism, flexibility, openness, technical and information equipment in the orientation to the regional, national and global levels (figure 1).

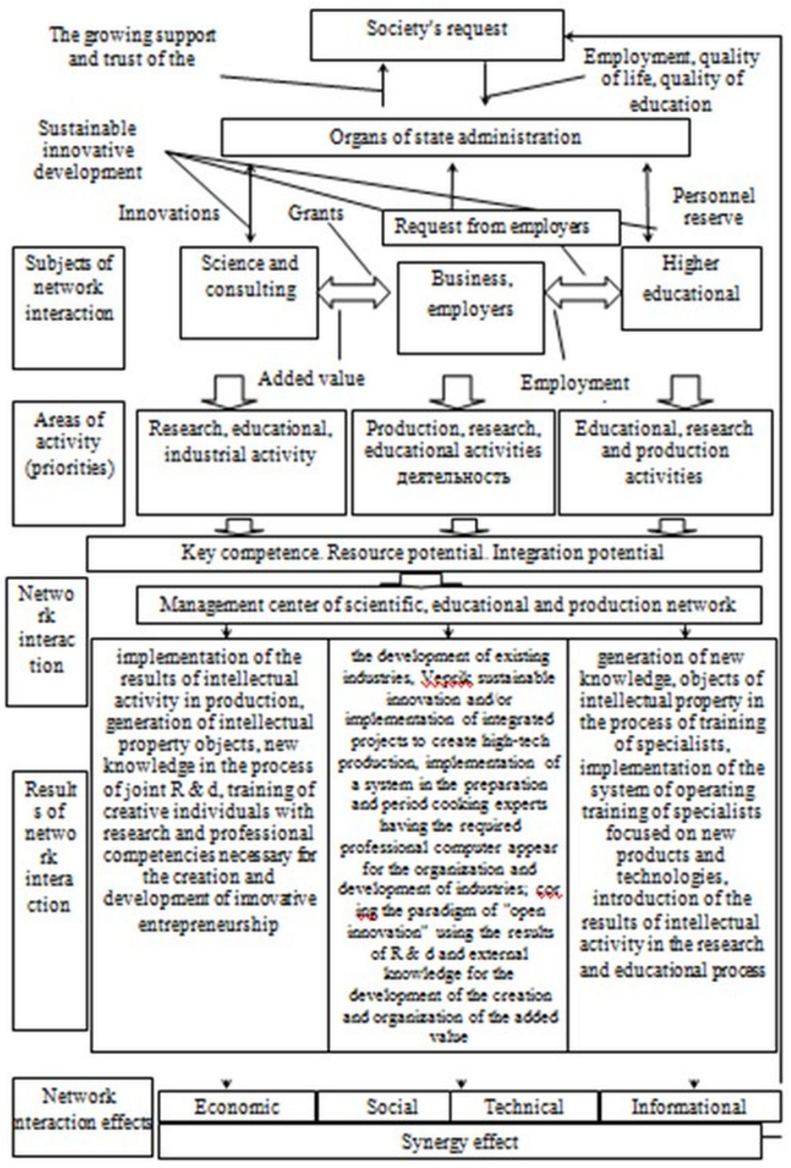

Fig. 1. Diagram of network interaction participants/ Note-Compiled by the authors.

Training of a modern specialist on the basis of integration of education, science and production is not only a scientific problem, but also a direction of state policy. Therefore, sustainable innovative development of the national economy requires achieving a balanced correspondence between the actual needs of science, the quality of training of University graduates and high-tech production. The external environment for the SEPN is made up of state education management bodies, industrial and educational organizations that are not part of the network interaction, but indirectly involved in creating conditions for the selfdevelopment of industrial enterprises, educational and scientific organizations within the 
network interaction, as well as the necessary information, technological and material resources.

Integration of science, education and production is a structural component of the national innovation system. The competence of a University graduate in these conditions is an integrative quality of personality, which is formed in the educational process through the acquisition of practical abilities to solve professional problems in the conditions of integration of science and education [17-20].

The synergetic effect of network interaction manifests itself in a fundamentally new quality of intellectual products that are created within each of the subsystems of the integrated system "science-education-production" and form a powerful potential for innovative development of all subjects of joint creative activity, a single educational space of science, University and production, demonstrates the model of achieving the quality of training of modern specialists $[21,22]$. The big data analysis opens huge prospects in various areas of activity - from public administration and control over social processes to the formation of entrepreneurial strategies. [23]

As you know, in the post-industrial economy, the free exchange of research results is the main factor in reducing the time of creation of innovative projects and increasing the competitiveness of innovative developments. Accordingly, it is legitimate to consider that the expanding scientific, educational and production network is the main source of synergetic rent for its members. The mentioned synergetic rent is created in the process of resource exchange, but it cannot be created by a separate organization. Therefore, in the methodology of formation of scientific-educational-production network synthesized competitive advantages, which are the result:

- organization of free exchange of information between its participants;

- creation of information environment for innovative projects;

- attraction of scientific competences and resources from outside;

- implementation of the strategy for the protection of intellectual property of all members of the network, which is a strict distribution of levels of access to the flow of information circulating in a multi-layer information space [24-26].

The structural and functional scheme of management of the scientific, educational and production network is shown in figure 2 .

The development of the information environment of the scientific, educational and production network is based on the use of "cloud" strategy, where there are 3 types of distributed infrastructures:

- private (internal clouds);

- partnership (the clouds that belong to the interacting partners);

- public (own cloud of scientific, educational and production network).

Using the strategy described above, we distinguish in the internal information space of the scientific, educational and production network (SEPN) 3 levels:

1st - information environment of the network, allowing to keep the network open, thereby stimulating the development of both internal and external to the network competitive environment;

2nd-external environment of the project, which is available for passive network members;

3rd-infoportal network with databases on projects of member organizations of the network, access to which is different for interested organizations.

Thus, the formed multilayered ordered network of information processes is a virtual information space (information "cloud") of the developing scientific, educational and production network.

The basis for the rational allocation of tasks SEPN lies the functional approach. Within the framework of the SEPN, the system coordination of activities is carried out by the 
SEPN activity management center, which is an integrated software and cybernetic system, which is the main integrator of all processes, formalized with the internal hierarchy of the integrated environment at certain levels of the scientific, educational and production network, as well as resources for innovative development and signals from the external information environment [27].

The need for the organization of the control center of scientific, educational and production network is determined by the following considerations.

1. Integration and unity of information processes imply common tools for managing these processes, which ultimately leads to a reduction in the cost of such management, including by combining scientific, innovative, educational processes in a single integrated information environment.

2. The progressive increase in the volume of information arrays and databases with different types of information requires the development of a management system for these arrays.

3. To manage the implementation of innovative projects in the network, the lack of a single information system reduces the efficiency of individual organizations due to the difficulties that arise when integrating participants into a single whole.

The activities of the SEPN control center are aimed at the implementation of the following important functions:

- marketing research;

- goal-setting;

- organization of innovation activities;

- planning (operational, tactical, strategic);

- motivation of network participants;

- analysis and regulation of ongoing processes;

- accounting and functional controlling.

\section{Conclusions}

The main structural components of the SEPN include:

- scientific component, which ensures the implementation of innovative projects of the SEPN with the participation of creative teams, uniting scientific, educational and industrial enterprises;

- an educational component that improves the quality of training and retraining of highly qualified personnel during training sessions; transfer of knowledge, skills and competencies obtained as a result of the development and implementation of specific projects into a single network space; the ability to use the production base of production enterprises - participants of interaction in network interaction projects;

- technical and implementation component, which provides the necessary conditions for the successful dissemination of research results in the educational practice of network participants.

The main result of the work of the SEPN is to ensure self-development and selforganization of the network, the creation of collective products of intellectual property.

\section{References}

1. World development indicators (2016)

2. B. S. Tolysbayev, K. A. Kirdasinova, \& R. Sabirova, Industrial innovative policy of Kazakhstan: current status and development prospects (2015)

3. National Agency for Technological Development (2013) 
4. T. Odinokova, M. Bozhinova, M. Petrova, E3S Web Conferences, 41, 04015 (2018)

5. R. Pukala, E. Sira, R. Vavrek, , Marketing and Management of Innovations, 3, 153 (2018)

6. L. Ibragimova, D. Abilkairov, G. Lesbekov, M. Tajmurzaev, E. Abdibekov, An M., Turebaeva, A. Ospanov, Otchet o sostojanii razvitija malogo $i$ srednego predprinimatel'stva $v$ Kazahstane i ego regionah (2015)

7. D. Iskakova, K. A. Kirdasinova, L. Sembiyeva, S. Makysh, G. Kazbekov, R. Sabirova, \& A. Umarbekova,. Journal of Economic \& Management Perspectives, 11:2, 418 (2017)

8. U. Bajmuratov, Garmonija obshhestva $i$ jekonomiki: mirovaja paradigm (Almaty: Jekonomika, 2010)

9. M. Petrova, M. Tepavicharova, L. Boykova, E3S Web of Conferences, 41, 04017, (2018)

10. M. Petrova, N. Dekhtyar, O. Klok and O. Loseva, Problems and Perspectives in Management, 16:4, 259 (2018)

11. N. Kurmanov, B. Beisengaliyev, A. Dogalov, D. Turekulova, \& N. Kurmankulova,. International Journal of Economics and Financial Issues, 6:4, 1140 (2016)

12. S.N. Alpysbaeva,. Proceedings of National Academy of Sciences of Kazakhstan. Social sciences and humanities Series, 4, 22 (2013)

13. N. Kurmanov, A. Yeleussov, U. Aliyev, \& B. Tolysbayev, Mediterranean Journal of Social Sciences, 6:5, 54 (2015)

14. R. Pukala, Engineering Management in Production and Services, 8:3, 43 (2016)

15. N. Kurmanov, B. Tolysbayev, D. Aibossynova, \& N. Parmanov,. Economic AnnalsXXI, 158:3-4, 57 (2016)

16. Sv. Labunska, M. Petrova, O. Prokopishyna, Economic Annals-XXI. 165:5-6, 13 (2017)

17. N. A. Ashford, American Behavioral Scientist, 45:9, 1417 (2002)

18. R. Moreno, R. Paci, \& S. Usai,. The Annals of Regional Science, 39:4, 715 (2005)

19. A. Yeleussov, N. Kurmanov, \& B. Tolysbayev,. Education quality assurance strategy in Kazakhstan, 2, 142 (2015)

20. N. Barbosa, , \& A. P. Faria,. Research Policy, 40:9, 1157 (2011)

21. M. Buesa, J. Heijs, \& T. Baumert, Research Policy, 39:6, 722 (2010)

22. Y. Dyachenko, N. Nenkov, M. Petrova, I. Skarga-Bandurova, O. Soloviov, Biologically Inspired Cognitive Architectures, Elsevier, 26, 130 (2018)

23. M. Petrova, O. Sushchenko, I. Trunina, N. Dekhtyar. IEEE First International Conference (SAIC-2018) 256 (2018)

24. Y. V. Smirnova, Quality Innovation: Knowledge, Theory, and Practices: Knowledge, Theory, and Practices, 322 (2013)

25. N. Kurmanov, D. Turekulova, G. Doskeyeva, G. Alina, International Journal of Economics and Financial Issues, 6:3, 907 (2016)

26. T. A. Kussainov, M. Maitah, N. A. Kurmanov, P. Hájek, B. S. Tolysbaev, A. K. Baidakov, Review of European Studies, 7:11, 125 (2015)

27. N. A. Kurmanov, B. K. Zhumanova, O. V. Kirichok, World Applied Sciences Journal, 21:10, 1495 (2013) 